\title{
Nyctalopia With Normal Rod Function: A Suppression of Cones by Rods
}

\author{
F. M. FALCAO-REIS,${ }^{*}$ C. R. HOGG, T. E. FRUMKES $\dagger$ and G. B. ARDEN \\ London
}

\begin{abstract}
Summary
Twenty-nine patients with exaggerated rod-cone interaction are described. All were referred because they appeared to suffer from night blindness. ERG and EOGs were performed but were normal. However, investigation with a modified dark-adaptometry technique showed that in these patients cone flicker thresholds rise considerably more during dark adaptation than is normal, and this is sufficient to explain the symptoms. In one case, the condition appears familial. Many patients report their symptoms begin in early adult life and slowly get worse, but we have no objective evidence of progression.
\end{abstract}

Symptoms of impaired visual adaptation are known as hemeralopia and nyctalopia. Hemeralopia or 'day blindness' is characterised by a defective cone function. Nyctalopia or 'night blindness', is a common symptom in many conditions which affect rods. It is the hallmark of retinitis pigmentosa, although it is not unusual to find RP patients without subjective nyctalopia, even in adult life. It also occurs, in a non progressive form, in the various forms of congenital stationary night blindness. Other causes include extreme myopia of more than 12-15 dioptres, which is associated with retinal degeneration. Endstage glaucoma results in nyctalopia, when the remaining field is so small that rod sensitivity is reduced. Nyctalopia due to vitamin A deficiency is, today, associated with chronic alcoholism and malabsorption syndromes. However, it has been recognised for a long time that many patients complaining of not seeing well at night fail to demonstrate any ocular or systemic abnormality. In some, the complaint is hysterical, but in others there seems to be a true difficulty in seeing at night and in these pathophysiological disturbance must be sought. The dark adaptation curve is the usual way of showing changes in the sensitivity of the eye. ${ }^{1}$ Following intense light adaptation, threshold is determined at various times in the dark. Log threshold light intensity, plotted against time of dark adaptation gives a curve with two distinct branches. First, the cones recover sensitivity over one or two minutes. At this time the rods are still very insensitive and threshold remains more or less constant for 9 to 12 minutes. Following this, continuing recovery of the rods causes a second slower decrease in threshold which lasts for 30-40 minutes. For clinical work, preadapting and stimulus conditions are standardised, and commonly only white light is used and a position 10 to 20 degrees from fixation is tested. To separate out rod

From: *Department of Ophthalmology, Oporto Medical School. Av Prof Hernani Monteiro, Oporto, Portugal. $\dagger$ Department of Psychology, CUNY, New York, USA.

From: Department of Clinical Ophthalmology, Institute of Ophthalmology, and Electrodiagnostic Department, Moorfields Eye Hospital.

Correspondence to: Electrodiagnostic clinic, Moorfields Eye Hospital, City Road, EC1V 2PD London, UK (Prof. Arden). 
from cone contributions, one can use red and blue light. However, because the scotopic system becomes extremely sensitive as time goes by, at the end of dark adaptation, the rod system responds to red flashes which are so dim that they cannot be detected by the cone system. At the end of dark adaptation, to get a response derived solely from the excitation of cones, it is necessary to exploit another difference between the classes of receptors, and it is convenient that rods cannot follow rapid alternation of light and dark. A flicker of $15 \mathrm{~Hz}$ or greater, especially if the stimulus wavelength is $>600 \mathrm{~nm}$, must be perceived by cones. Thus, the time course of dark-adaptation of cones and rods can be measured separately using red flickering light and single flashes of short wavelength light. One therefore could expect that after the rod-cone break (the knee in the dark adaptation curve) cone flicker threshold would remain constant until the end of dark-adaptation. This is not the case: at around the time of the rod-cone break the cone flicker threshold begins to rise. This phenomenon reflects a suppressive interaction between the scotopic and photopic retinal systems. $^{2-4}$

The interaction, however, is absent, if the frequency of the red flicker is decreased as is clearly seen in Figure 1 which shows a darkadaptation curve in a person who has normal rod-cone interaction. Under our test conditions the increase in flicker threshold during the rod phase of dark adaptation is about 0.6-1 log unit. Some perons however, have an exaggerated effect, ie the flicker threshold rises by more than $1 \log$ unit. ${ }^{5}$ In such persons, it is common to find the complaint of nyctalopia, even though the rod threshold is perfectly normal. On close questioning, such persons describe a diminution in their visual abilities at night, but the functions they lose are those mediated by cones, not by rods, and specifically, they complain of difficulty in driving. They may complain of glare, but frequently say that they cannot see the kerb markings or traffic lights. The difficulties are so great that none of these patients will drive at night. By contrast patients with real nyctalopia (eg caused by retinitis pigmentosa) are reluctant to stop driving at night even when advised to do so by their ophthalmologist. Since the first description of this syndrome, we have tested for it routinely and in this paper report on 29 cases in whom the exaggerated rod-cone interaction was the only abnormality to explain their disability.

\section{Material and Methods}

Patients were seen at the Electrodiagnostic Clinic, Moorfields Eye Hospital, to investigate what had been considered to be a night blindness problem or to clarify situations where a particular finding on the fundoscopy or dubious family history raised suspicion of a heredodegenerative disorder. They were investigated by standard clinical techniques such as $\mathrm{EOG}^{6}$ and the ERG, ${ }^{7}$ the latter using an extended protocol. In addition, dark adaptometry had been carried out by a computerised instrument, which enables cone and rod thresholds to be determined separately.

\section{$E O G$}

Electrodes were attached to the skin overlying the bony margins of the orbit opposite the lateral and medial canthi. A ground electrode was placed on the forehead. Patients made a number of voluntary horizontal eye movements between two fixation spots, separated by 30 degrees. This was repeated every minute. Readings were taken for 12 minutes with lights off and 8 minutes with lights on. Potentials were amplified in a Medelec MS6, with a bandpass of $0.5-50 \mathrm{~Hz}$ and printed. The ratio light peak/light trough $\times 100$ was calculated.

\section{$E R G$}

Earth and reference electrodes were $10 \mathrm{~mm}$ silver-silver chloride discs which were placed on the forehead. The active electrode was a gold foil electrode placed in the lower fornix usually without anaesthesia. A Grass PS22 stroboscope was used to back illuminate a rectangle of $3 \mathrm{~mm}$ thick opal Perspex placed $4 \mathrm{~cm}$ from the patient's nose. The diffusion of light through the perspex presents a uniform field of so large an extent that it can be considered a Ganzfeld. Between the stroboscope and the diffuse screen a number of coloured or neutral filters were inserted, which together with the controls on the stroboscope unit provided a range of light intensities over 


\section{SUPPRESSIVE ROD-CONE INTERACTION NORMAL OBSERVER}

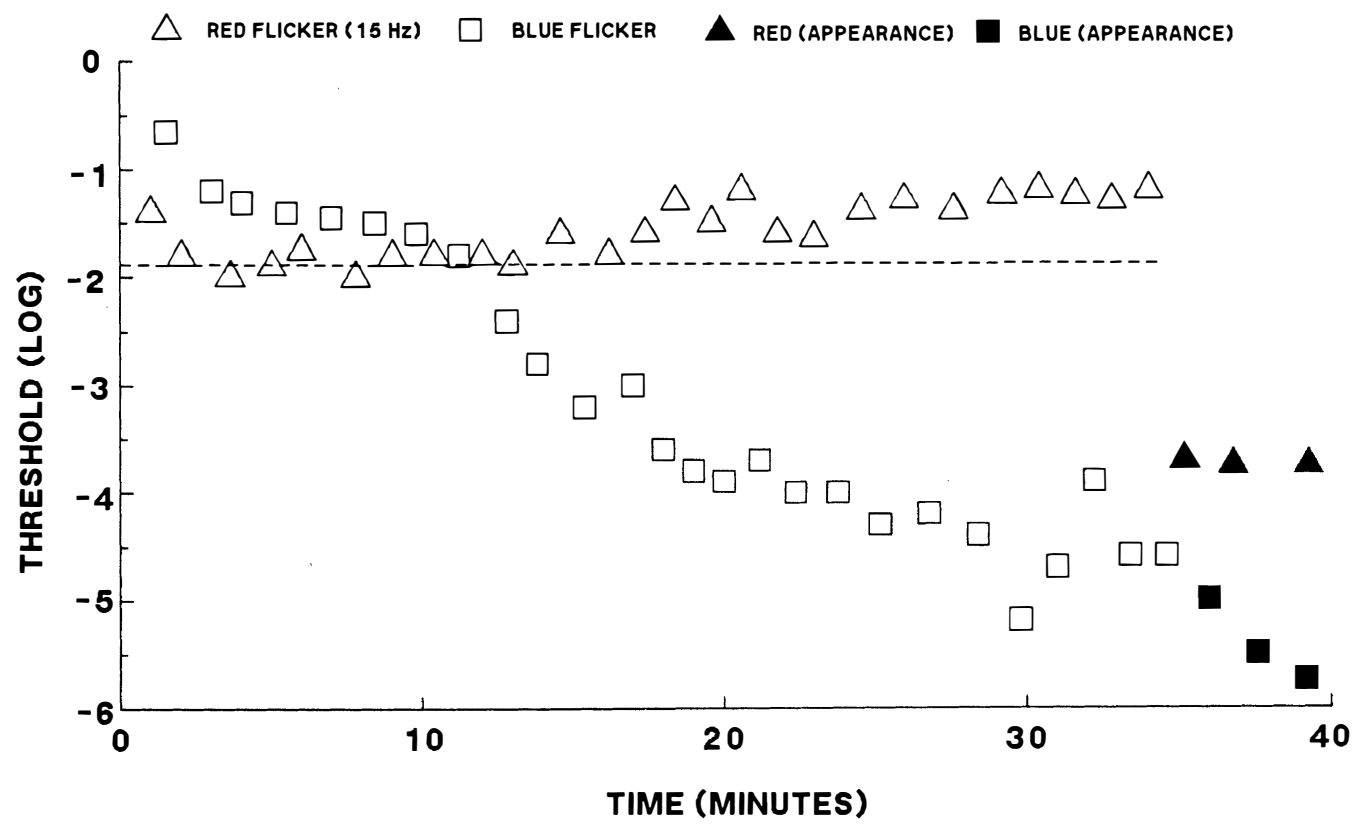

Fig. 1. Dark adaptation curves obtained from a subject showing normal rod-cone interaction. For full description see text. Note that after the 'knee' the red flicker threshold rises. The dashed line shows the threshold expected in the absence of rod-cone interaction.

4.4 logs units. Records were obtained with a Medelec MS 6 polygraph system, which includes an artifact rejection system. Potentials were amplified $\times 10,000$, with a bandpass $0.16 \mathrm{~Hz}$ to $1.6 \mathrm{KHz}$. Between 16 and 64 responses were averaged. Patients' pupils were dilated with one per cent cyclopentolate, and they were dark adapted at least for 20 minutes with dark-room goggles. A further time, $>10 \mathrm{~min}$, was spent in complete darkness before recordings began.

A series of intensities of blue, red and white flashes were given. The repetition rate varied with the flash intensity but was never more frequent than $1 / \mathrm{sec}$. The $\mathrm{a}-$ and $\mathrm{b}$-waves, oscillatory potentials and cone flicker responses were analysed. The large range of intensity of the stimulus allows for the study of the intensity-amplitude relation.

\section{Dark Adaptometry}

A modified Lister perimeter, with target replaced by light emitting diodes, LEDs, and added computer control was used. The technique has been described elsewhere. ${ }^{8}$ Since that publication, the green LEDs have been replaced by blue (Siemens, peak emission $480 \mathrm{~nm}$ ) and an infra-red TV camera has been installed to monitor patient fixation. A one degree red $(660 \mathrm{~nm})$ or blue $(480 \mathrm{~nm})$ stimulus can be placed anywhere in the visual field. Rod-cone interaction was measured at $10^{\circ}$ nasally in the horizontal meridian. A fixation spot was provided by a dim red LED.

Patients' pupils were dilated by instillation of one per cent cyclopentolate and light adapted by examining them for 30 seconds with the full intensity of an indirect ophthalmoscope with a 20D lens, a technique previously described. In this way almost all rhodopsin was bleached. The cone stimulus was a red LED which flickered at $15 \mathrm{~Hz}$, square wave modulation, while the intensity was slowly ramped up from a variable, randomly set level which was well below visual threshold. The stimulus was controlled 
by the computer. The patient pressed a button when he saw the flicker, and the test was repeated until the standard deviation of the results was $<0.4 \mathrm{log}$ unit. A blue rectangular wave stimulus at $1 \mathrm{~Hz}$ was used to measure the rod threshold in the same way: this sequence was repeated, and the programme then waited for a new cycle to be set manually. The test was carried on for at least 10 minutes. Finally, two or three determinations of cone absolute threshold to a $1 \mathrm{~Hz}$ red rectangular wave were carried out.

\section{Results}

Figure 1 shows a normal representative dark adaptation curve. Open squares show the threshold to the perception of the presence of a blue stimulus, flashing at $15 \mathrm{~Hz}$. To the observer, such a stimulus appears continuous, and only its presence or absence can be distinguished. The open triangles show thresholds to the perception of flicker for a red light flickering at $15 \mathrm{~Hz}$ (see methods). In the absence of severe rod disease the sensations elicited by these two stimuli are evoked by rods and cones respectively. Cone thresholds are initially elevated, but fall so rapidly to a plateau that until the 'knee' of the dark adaptation curve, cone thresholds are constant. In the minutes following the knee, the cone threshold rises by 0.8 of a log unit. Solid triangles and squares represent thresholds to a stimulus which always consisted of a single, $0.2 \mathrm{sec}$ flash. With such stimuli, the rod thresholds decrease slightly, because the light is continuous for the duration for which temporal summation can occur, while for the flickering blue light, with a $50 \%$ duty cycle, the light intensity is reduced by $0.3 \mathrm{log}$ unit. For the cone stimuli, the threshold reduces, partly because it is much esier to detect the presence of the red light than to decide whether it is flickering. The ordinate light intensities are similar to the calibration on the Goldmann-Weekers dark adaptometer. It can be seen that the absolute threshold for red light (filled triangles) compared to blue is as previously described for that instrument and for our own work. ${ }^{8}$ The dashed line shows the expected cone threshold if there was no rodcone interaction (as happens in some diseases).
Figure 2 shows dark adaptation curves from two relatives in whom exaggerated 'suppressive rod-cone interaction' had been diagnosed. It can be seen that the cone flicker threshold, after the rod-cone break rises by much more than 1 log unit. Indeed, no flicker could be observed with the maximum light available. This increase is larger than in normal observers (the mean for 5 syptom-free 'normal' observers is represented by a dotted line). Rod function is normal as can be assessed by time of rod-cone break, around 10 minutes, and a subsequent $>3 \log$ units increase in scotopic retinal sensitivity. The cone threshold to a $1 \mathrm{~Hz}$ square wave show no sensitivity loss. The interval between detection of the light and the detection of flicker in the normal is $2 \log$ unit: in the patients it is $>4$ log unit. A normal appearance threshold indicates that the interaction is limited to flicker presentation. (and it also confirms patients' understanding of the test).

Twenty-five patients underwent both EOG and ERG investigation. A few had only one of these tests. All showed no electrophysiological evidence of rod or cone dysfunction. Increase in red flicker threshold was equal or larger than $1.2 \mathrm{log}$ units and in some cases thresholds rose more than $2.5 \mathrm{log}$ units. Seven patients out of 29 failed to detect any flicker with the brightest stimulus our device can produce although in light adaptation, the flicker was obvious.

Some patients feel that their symptoms are becoming more marked. We retested three patients at an interval greater than four years but did not succeed in demonstrating an increase in rod-cone interaction. However, one of our patients was an amateur astronomer, who had a complicated malabsorption syndrome and developed an avitaminosis $\mathrm{A}$. After correction of the vitamin A level, by intramuscular injection, his rod visual threshold recovered to normal, but he still complained of night blindness, and we discovered exaggerated rod-cone interaction. Since this patient had monitored his own loss of rod sensitivity by noting how the number of the Pleiades visible to him was decreasing, it is very likely he would have detected any abnormality of rod-cone interaction had it been present earlier in life. The relationship 


\section{SUPPRESSIVE ROD-CONE INTERACTION EXAGGERATED ROD-CONE INTERACTION}

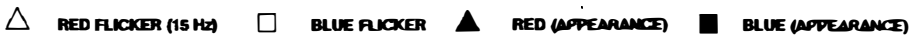

A

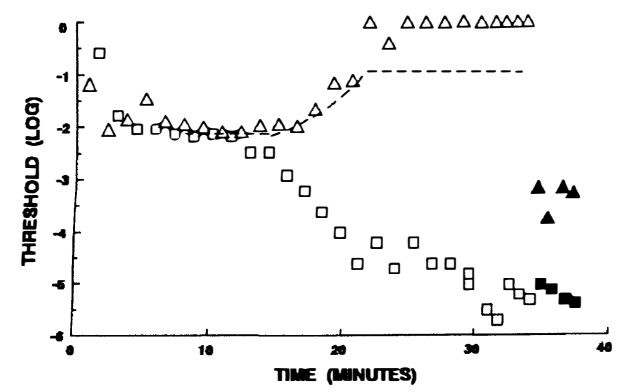

B

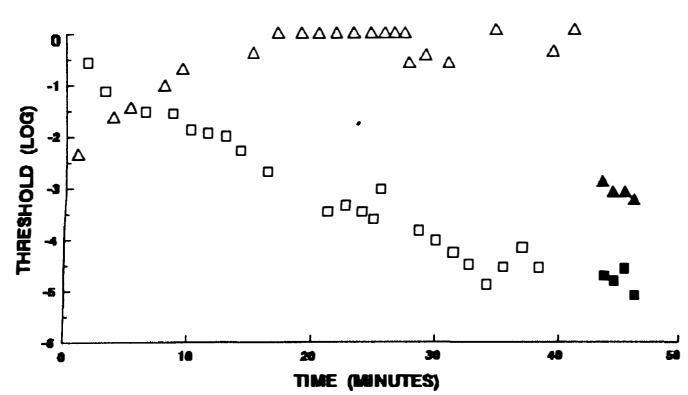

Fig. 2. Dark adaptation curves obtained in two relatives of a propositus with exaggerated rod-cone interaction. The dashed line, represents the mean of rod-cone interaction in five normal observers. In spite of some variation in the shape of curves the exaggerated rod-cone interaction is quite evident in both cases. A: the mother and B: the son of the propositus.

to his other condition is being investigated. A family history of similar complaints was frequently obtained. It is not clear if the families' similar symptoms were related to the same condition. In only one case was it possible to investigate relatives. The propositus was unfortunately a poor observer, but had exaggerated rod cone interaction and in dark adaptation was unable to perceive any flicker at the maximal intensity of our equipment. Figure 2 shows dark-adaptation for the mother, and brother of the propositus. In spite of some variation in the shape of the curves, exaggerated rod-cone interaction is quite evident in both traces.

Histories are often very suggestive of reduced cone function under dark-environment. For instance patient No 29, who is a corporal had never complained of nyctalopia. He was a good shot during the day but noticed his performance was poor during night training. Patient No 18 is from Singapore and was attending a postgraduate course in London. She was not able to drive at night in London but had no difficulty in Singapore where night illumination level is six times brighter.

Table I shows a summary of clinical findings in 29 patients with an increase rod-cone interaction.

The mean age was $34 \pm 11$ years. There was a female predilection (34\% male, $66 \%$ female) but no significant difference between sex (Fisher exact test $p=0.212$ ). Most patients were Caucasian whilst two were Asian. Seven patients had visual acuity less than $6 / 6$, but in only one person was there not some reason to account for this. Thus, drusen had been found in one patient, and discrete macular pigmentary changes in another. There was no relationship between the condition and refractive error, and in particular the myopes had but moderate errors $(<4$ dioptres), and no signs of myopic degeneration. Twenty-four per cent had reported that a relative had similar complaints, namely difficulty in driving at night.

\section{Discussion}

That rods and cones do not not always act independently is now well established (for a recent review see Denny et al). ${ }^{9}$ Electrophysiological data show that rod and cones interact in at least two ways. The first is called summatory rod-cone interaction in which separate rod- and cone-mediated responses can influence some common locus and sum together.

A second form called suppressive rod-cone interaction is characterised by an inhibitory influence of rods upon cones, that is removed by light-adapting the rods. Although the exact mechanism of rod-cone interaction remains to be determined, data from animal experiments 
Table I. Summary of Clinical Findings

\begin{tabular}{|c|c|c|c|c|c|c|c|c|c|c|}
\hline No. & Eye & Sex & Age & $V / A$ & Refraction & $\begin{array}{c}\text { Ocular } \\
\text { Examination }\end{array}$ & $\begin{array}{l}\text { Presenting } \\
\text { Symptoms }\end{array}$ & $\begin{array}{l}\text { Family } \\
\text { History }\end{array}$ & $\begin{array}{c}\text { Ocular or } \\
\text { Systemic } \\
\text { Disease }\end{array}$ & $\begin{array}{l}\text { Rod- } \\
\text { Cone } \\
\text { Intera }\end{array}$ \\
\hline 1 & $\begin{array}{l}\mathrm{R} \\
\mathrm{L}\end{array}$ & $\mathrm{F}$ & 20 & $\begin{array}{l}6 / 5 \\
6 / 5\end{array}$ & $\begin{array}{c}\text { Emmetrope } \\
\text { Myope }\end{array}$ & $\begin{array}{l}\text { Normal } \\
\text { Normal }\end{array}$ & Nyctalopia & No & No & 2.00 \\
\hline 2 & $\mathrm{R}$ & $\mathrm{F}$ & 58 & $\begin{array}{l}6 / 5 \\
6 / 5\end{array}$ & $\begin{array}{l}\text { Hypermet. } \\
\text { Hypermet. }\end{array}$ & $\begin{array}{l}\text { Normal } \\
\text { Normal }\end{array}$ & $\begin{array}{l}\text { Night** } \\
\text { Driving }\end{array}$ & No & No & $>1.5$ \\
\hline 3 & $\begin{array}{l}\mathrm{R} \\
\mathrm{L}\end{array}$ & $\mathrm{F}$ & 23 & $\begin{array}{l}6 / 6 \\
6 / 6\end{array}$ & $\begin{array}{l}\text { Myope } \\
\text { Myope }\end{array}$ & $\begin{array}{l}\text { Discrete } \\
\text { Pig Chan. }\end{array}$ & Nyctalopia & No & No & 2.00 \\
\hline 4 & $\begin{array}{l}\mathrm{R} \\
\mathrm{L}\end{array}$ & $\mathbf{M}$ & 27 & $\begin{array}{l}6 / 5 \\
6 / 9\end{array}$ & $\begin{array}{l}\text { Hypermet. } \\
\text { Hypermet. }\end{array}$ & $\begin{array}{l}\text { Normal } \\
\text { Normal }\end{array}$ & Nyctalopia & No & No & 2.00 \\
\hline 5 & $\begin{array}{l}\mathrm{R} \\
\mathrm{L}\end{array}$ & $\mathbf{M}$ & 35 & $\begin{array}{l}6 / 5 \\
6 / 5\end{array}$ & $\begin{array}{c}\text { Myope } \\
\text { Myop.+ Ast. }\end{array}$ & $\begin{array}{l}\text { Normal } \\
\text { Normal }\end{array}$ & $\begin{array}{l}\text { Night } \\
\text { Driving }\end{array}$ & Yes & No & 2.00 \\
\hline 6 & $\begin{array}{l}\mathrm{R} \\
\mathrm{L}\end{array}$ & $\mathrm{F}$ & 52 & $\begin{array}{l}6 / 5 \\
6 / 5\end{array}$ & $\begin{array}{l}\text { Emmetrope } \\
\text { Emmetrope }\end{array}$ & $\begin{array}{l}\text { Normal } \\
\text { Scotoma }\end{array}$ & $\begin{array}{l}\text { Night } \\
\text { Driving }\end{array}$ & No & Glaucoma** & 2.00 \\
\hline 7 & $\begin{array}{l}\mathrm{R} \\
\mathrm{L}\end{array}$ & $\mathrm{F}$ & 24 & $\begin{array}{l}6 / 6 \\
6 / 6\end{array}$ & $\begin{array}{l}\text { Emmetrope } \\
\text { Emmetrope }\end{array}$ & $\begin{array}{l}\text { Normal } \\
\text { Normal }\end{array}$ & $\begin{array}{l}\text { Night } \\
\text { Driving }\end{array}$ & No & $\begin{array}{c}\text { Glaucoma** } \\
\text { Arthritis }\end{array}$ & $>1.2$ \\
\hline 8 & $\begin{array}{l}\mathrm{R} \\
\mathrm{L}\end{array}$ & $\mathrm{F}$ & 30 & $\begin{array}{l}6 / 5 \\
6 / 5\end{array}$ & $\begin{array}{l}\text { Emmetrope } \\
\text { Emmetrope }\end{array}$ & $\begin{array}{l}\text { Normal } \\
\text { Scotoma }\end{array}$ & $\begin{array}{l}\text { Night } \\
\text { Driving }\end{array}$ & No & No & $>2.5$ \\
\hline 9 & $\begin{array}{l}\mathrm{R} \\
\mathrm{L}\end{array}$ & $\mathrm{F}$ & 21 & $\begin{array}{l}6 / 9 \\
6 / 9\end{array}$ & $\begin{array}{l}\text { Emmetrope } \\
\text { Emmetrope }\end{array}$ & $\begin{array}{l}\text { Normal } \\
\text { Normal }\end{array}$ & $\begin{array}{l}\text { Night } \\
\text { Driving }\end{array}$ & No & No & 1.10 \\
\hline 10 & $\begin{array}{l}\mathrm{R} \\
\mathrm{L}\end{array}$ & $\mathrm{M}$ & 54 & $\begin{array}{c}6 / 6 \\
-\end{array}$ & $\begin{array}{c}\text { Emmetrope } \\
\text { Ambl. }\end{array}$ & $\begin{array}{l}\text { Normal } \\
\text { Normal }\end{array}$ & $\begin{array}{l}\text { Night } \\
\text { Driving }\end{array}$ & No & Congenital & 2.00 \\
\hline 11 & $\begin{array}{l}\mathrm{R} \\
\mathrm{L}\end{array}$ & $\mathbf{M}$ & 19 & $\begin{array}{l}6 / 6 \\
6 / 6\end{array}$ & $\begin{array}{l}\text { Myop.+Ast. } \\
\text { Myop. + Ast. }\end{array}$ & $\begin{array}{l}\text { Macular } \\
\text { Changes }\end{array}$ & Nyctalopia & No & $\begin{array}{l}\text { Stargardt's } \\
\text { Suspected }\end{array}$ & 2.00 \\
\hline 12 & $\begin{array}{l}\mathrm{R} \\
\mathrm{L}\end{array}$ & $\mathbf{M}$ & 34 & $\begin{array}{l}6 / 5 \\
6 / 5\end{array}$ & $\begin{array}{l}\text { Myope } \\
\text { Myope }\end{array}$ & $\begin{array}{l}\text { Normal } \\
\text { Normal }\end{array}$ & $\begin{array}{l}\text { Night } \\
\text { Driving }\end{array}$ & Yes & No & 1.30 \\
\hline 13 & $\begin{array}{l}\mathrm{R} \\
\mathrm{L}\end{array}$ & $\mathrm{F}$ & 31 & $\begin{array}{l}6 / 5 \\
6 / 5\end{array}$ & $\begin{array}{l}\text { Myop. + Ast. } \\
\text { Myop. + Ast. }\end{array}$ & $\begin{array}{l}\text { Drusen? } \\
\text { Normal }\end{array}$ & Nyctalopia & Yes & No & $>1.3$ \\
\hline 14 & $\begin{array}{l}\mathrm{R} \\
\mathrm{L}\end{array}$ & $\mathrm{F}$ & 39 & $\begin{array}{l}6 / 5 \\
6 / 5\end{array}$ & $\begin{array}{l}\text { Emmetrope } \\
\text { Emmetrope }\end{array}$ & $\begin{array}{l}\text { Normal } \\
\text { Normal }\end{array}$ & $\begin{array}{l}\text { Night } \\
\text { Driving }\end{array}$ & No & No & 2.50 \\
\hline 15 & $\begin{array}{l}\mathrm{R} \\
\mathrm{L}\end{array}$ & $\mathrm{F}$ & 42 & $\begin{array}{l}6 / 5 \\
6 / 9\end{array}$ & $\begin{array}{l}\text { Emmetrope } \\
\text { Emmetrope }\end{array}$ & $\begin{array}{l}\text { White } \\
\text { Spots }\end{array}$ & Nyctalopia & No & No & 2.50 \\
\hline 16 & $\begin{array}{l}\mathrm{R} \\
\mathrm{L}\end{array}$ & $\mathbf{M}$ & 42 & $\begin{array}{l}6 / 5 \\
6 / 5\end{array}$ & $\begin{array}{l}\text { Emmetrope } \\
\text { Emmetrope }\end{array}$ & $\begin{array}{l}\text { Normal } \\
\text { Normal }\end{array}$ & Nyctalopia & No & $\begin{array}{l}\text { Malabsorption } \\
\text { Syndrome }\end{array}$ & 1.50 \\
\hline 17 & $\begin{array}{l}\mathrm{R} \\
\mathrm{L}\end{array}$ & $\mathrm{F}$ & 26 & $\begin{array}{l}6 / 5 \\
6 / 5\end{array}$ & $\begin{array}{l}\text { Myope } \\
\text { Myope }\end{array}$ & $\begin{array}{l}\text { Normal } \\
\text { Normal }\end{array}$ & $\begin{array}{c}\text { Night } \\
\text { Driving }\end{array}$ & Yes & No & $>2.5$ \\
\hline 18 & $\begin{array}{l}\mathrm{R} \\
\mathrm{L}\end{array}$ & $\mathrm{F}$ & 25 & $\begin{array}{l}6 / 5 \\
6 / 5\end{array}$ & $\begin{array}{l}\text { Myope } \\
\text { Myope }\end{array}$ & $\begin{array}{l}\text { Normal } \\
\text { Normal }\end{array}$ & $\begin{array}{c}\text { Night } \\
\text { Driving }\end{array}$ & No & No & 2.00 \\
\hline 19 & $\begin{array}{l}\mathrm{R} \\
\mathrm{L}\end{array}$ & $\mathrm{F}$ & 42 & $\begin{array}{l}6 / 5 \\
6 / 5\end{array}$ & $\begin{array}{l}\text { Emmetrope } \\
\text { Emmetrope }\end{array}$ & $\begin{array}{l}\text { Normal } \\
\text { Normal }\end{array}$ & Nyctalopia & No & No & 1.60 \\
\hline 20 & $\begin{array}{l}\mathrm{R} \\
\mathrm{L}\end{array}$ & $\mathrm{F}$ & 26 & $\begin{array}{l}6 / 9 \\
6 / 9\end{array}$ & $\begin{array}{l}\text { Myop. + Ast. } \\
\text { Myop. + Ast. }\end{array}$ & $\begin{array}{l}\text { Normal } \\
\text { Normal }\end{array}$ & $\begin{array}{l}\text { Night } \\
\text { Driving }\end{array}$ & No & No & 1.20 \\
\hline 21 & $\begin{array}{l}\mathrm{R} \\
\mathrm{L}\end{array}$ & $\mathbf{M}$ & 34 & $\begin{array}{l}6 / 5 \\
6 / 5\end{array}$ & $\begin{array}{l}\text { Myope } \\
\text { Myope }\end{array}$ & $\begin{array}{l}\text { Normal } \\
\text { Normal }\end{array}$ & $\begin{array}{l}\text { Night } \\
\text { Driving }\end{array}$ & No & No & $>2.0$ \\
\hline 22 & $\begin{array}{l}\mathrm{R} \\
\mathrm{L}\end{array}$ & $\mathrm{F}$ & 48 & $\begin{array}{l}6 / 5 \\
6 / 5\end{array}$ & $\begin{array}{l}\text { Emmetrope } \\
\text { Emmetrope }\end{array}$ & $\begin{array}{l}\text { Normal } \\
\text { Normal }\end{array}$ & $\begin{array}{l}\text { Night } \\
\text { Driving }\end{array}$ & No & No & 1.80 \\
\hline 23 & $\begin{array}{l}\mathrm{R} \\
\mathrm{L}\end{array}$ & $\mathrm{F}$ & 21 & $\begin{array}{l}6 / 18 \\
6 / 18\end{array}$ & $\begin{array}{l}\text { Hypermet. } \\
\text { Hypermet. }\end{array}$ & $\begin{array}{l}\text { Amblyopia } \\
\text { Amblyopia }\end{array}$ & Nyctalopia & No & No & 2.00 \\
\hline 24 & $\begin{array}{l}\mathrm{R} \\
\mathrm{L}\end{array}$ & $\mathbf{M}$ & 39 & $\begin{array}{l}6 / 5 \\
6 / 5\end{array}$ & $\begin{array}{l}\text { Emmetrope } \\
\text { Emmetrope }\end{array}$ & $\begin{array}{l}\text { Normal } \\
\text { Normal }\end{array}$ & Nyctalopia & No & No & 1.20 \\
\hline 25 & $\begin{array}{l}\mathrm{R} \\
\mathrm{L}\end{array}$ & $\mathrm{F}$ & 55 & $\begin{array}{l}6 / 5 \\
6 / 5\end{array}$ & $\begin{array}{l}\text { Emmetrope } \\
\text { Emmetrope }\end{array}$ & $\begin{array}{l}\text { Normal } \\
\text { Normal }\end{array}$ & $\begin{array}{l}\text { Night } \\
\text { Driving }\end{array}$ & No & No & 2.50 \\
\hline 26 & $\begin{array}{l}\mathrm{R} \\
\mathrm{L}\end{array}$ & $\mathbf{M}$ & 30 & $\begin{array}{l}6 / 5 \\
6 / 5\end{array}$ & $\begin{array}{l}\text { Emmetrope } \\
\text { Emmetrope }\end{array}$ & $\begin{array}{l}\text { Normal } \\
\text { Normal }\end{array}$ & $\begin{array}{l}\text { Night } \\
\text { Driving }\end{array}$ & Yes & No & 2.00 \\
\hline 27 & $\begin{array}{l}\mathrm{R} \\
\mathrm{L}\end{array}$ & $\mathrm{F}$ & 24 & $\begin{array}{l}6 / 5 \\
6 / 5\end{array}$ & $\begin{array}{l}\text { Myope } \\
\text { Myope }\end{array}$ & $\begin{array}{l}\text { Normal } \\
\text { Normal }\end{array}$ & Nyctalopia & Yes & No & 1.20 \\
\hline 28 & $\begin{array}{l}\mathrm{R} \\
\mathrm{L}\end{array}$ & $\mathrm{F}$ & & $\begin{array}{l}6 / 6 \\
6 / 6\end{array}$ & $\begin{array}{l}\text { Astigmatism } \\
\text { Astigmatism }\end{array}$ & $\begin{array}{l}\text { Normal } \\
\text { Normal }\end{array}$ & $\begin{array}{l}\text { Night } \\
\text { Driving }\end{array}$ & Yes & No & 1.80 \\
\hline 29 & $\begin{array}{l}\mathrm{R} \\
\mathrm{L}\end{array}$ & $\mathbf{M}$ & 30 & $\begin{array}{l}6 / 5 \\
6 / 5\end{array}$ & $\begin{array}{l}\text { Myopia } \\
\text { Myopia }\end{array}$ & $\begin{array}{l}\text { Normal } \\
\text { Normal }\end{array}$ & $\begin{array}{l}\text { Night-time } \\
\text { Military } \\
\text { Exercises }\end{array}$ & No & No & $>1.8$ \\
\hline
\end{tabular}

* Complaint specific to driving at night

** Minor field defect.

as well as clinical observations have lead to several models of the interaction. Goldberg $e t$ $a l^{3}$ suggested an interaction mediated by a lateral pathway within the outer retina. Moreover, it has been shown ${ }^{10}$ that horizontal cells exert a continuous negative feedback onto cones in darkness. Consistent with these findings is recent work in which pharmacologic agents were used to selectively block specific cell types. ${ }^{11}$ Evidence for a post-synaptic mechanism comes also from psychophysical tests in humans. ${ }^{12,13}$

In the patients described a significant increase in cone flicker threshold during dark adaptation was the only definite abnormality found. Electrophysiology and dark adap- 
tation revealed no cone or rod dysfunction. It is plausible, therefore, to suggest that the suppressive type of rod-cone interaction is related to the cause of their complaints. Although we have only tested temporal flicker, Frumkes ${ }^{14}$ has shown that the interaction affects spatial contrast sensitivity, so that as the effect increases during the course of dark adaptation, both subjective brightness and resolution decreases. The process does not commence immediately and takes several minutes to complete. During this period, the patient must notice her/his perceptions fail in a progressive manner: this makes the disability obvious, and explains why our patients, unlike other nyctalopes, are so frightened that they do not wish to drive at night.

Some patients have described a late onset of the condition, in adult life and have claimed the condition gets worse with time. We have no evidence from our data that this occurs, or that the condition develops into any known retinal disorder in any of our patients. However, the condition does appear to be familial. The presenting symptom of RP and exaggerated rod-cone interaction is the same-night blindness. The authors' clinic sees tertiary referrals, and we know that many cases of RP, seen in the hospital by our colleagues, are not referred to us, since the diagnosis is certain, and many ophthalmologists are unconvinced of the value of electroretinography in such cases. In just the same way, many patients complaining of nyctalopia with normal fundi will be dismissed, so the proportion of the total population of new RP patients referred to this clinic is likely to be roughly the same as for the nyctalopes. In the 11 months preceding the composition of this manuscript, 29 new patients with RP were referred to the clinic: the 29 patients whose data are described above were referred over a period of four years. Thus, the incidence of the condition in the population as a whole may be as high at one in 20,000 , one quarter of the incidence of RP, and much greater than the incidence of the the various forms of true congenital stationary night blindness. ${ }^{15}$

This work was made possible by a grant to T. E. Frumkes: it was also supported in part by assistance from the Wellcome Foundation. F. Falcao-Reis gratefully acknowledges a Fellowship from the Gulbenkian Foundation, Lisbon.

Key words: Cones, dark-adaptation, night blindness, rods, rod-cone interaction.

\section{References}

${ }^{1}$ Ripps H: Night blindness revisited: from man to molecules. Invest Ophthalmol Vis Sci 1980, 23: 582-609.

${ }^{2}$ Coletta NJ and Adams AJ: Rod-cone interaction in flicker detection. Vision Res 1984, 24: 1330-40.

${ }^{3}$ Goldberg SH, Frumkes TE, Nygaard RW: Inhibitory influence of unstimulated rods in the human retina; evidence provided by examining cone flicker. Science, N.Y. 1983, 211: 180-2.

${ }^{4}$ Frumkes TE and Eysteinsson T: Suppressive rodcone interaction in distal vertebrate retina: intracellular records from Xenopus and Necturus. $J$ Neurophysiol 1987, 57: 1361-83.

${ }^{5}$ Arden GB and Hogg CR: A new cause for not seeing in the dark. Documenta Opthal Proc Ser 1984, 60: $121-5$.

${ }^{6}$ Arden GB, Barrada A, Kelsey JH: New clinical test of retinal function based upon the standing potential of the eye. Br J Ophthalomol 1962, 46: 440.

${ }^{7}$ Arden GB, Carter RM, Hogg CR, Powell DJ, Ernst WJ, Glover GM, Lyness AL, Quinlan MP: A modified ERG technique and the results obtained in $\mathrm{x}$-linked retinite pigmentosa. Br J Ophthalmol 1983, 67: 419-30.

${ }^{8}$ Ernst W, Faulkner DJ, Hogg CR, Powell DJ, Arden GB, Vaegan: An automated static perimeter/ adaptometer using light emitting diodes. $\mathrm{Br} \mathrm{J}$ Ophthalmol 1983, 67: 431-42.

${ }^{9}$ Denny N, Frumkes TE, Goldberg SH: Comparison of summatory and suppressive rod-cone interaction. Clin Vis Sci 1990, 5: 27-36.

${ }^{10}$ Murakami M, Shimoda Y, Nakatani K, Miyachi E, Watanable S: GABA-mediated negative feedback from horizontal cells to cones in carp retina. Jap J Physiol 1982, 32: 911-26.

${ }^{11}$ Eysteinsson T and Frumkes TE: Physiological and pharmacologic analysis of suppressive rod-cone interaction in necturus retina. J Neurophysiol 1989, 61: 866-77.

${ }^{12}$ Arden GB and Hogg CR: Rod cone interaction and analysis of retina; disease. Br J Ophthalmol 1984, 69: 404-15.

${ }^{13}$ Arden GB and Frumkes TE: Stimulation of rods can increase cone flicker ERGs in man. Vision Res 1986, 5: 711-21.

${ }^{14}$ Frumkes TE. Tonic inhibition of cone pathway by rods in distal vertebrate retina. Invest Opthalmol Vis Sci (Supp) 1987, 28: 50.

${ }^{15}$ Sharpe DM, Arden GB, Kemp CM, Hogg CR, Bird AC. Mechanisms and sites of loss of scotopic sensitivity: a clinical analysis of congenital stationary night blindness. Cli Vis Sci 1990, 51: 217-30. 